\title{
Early Childhood Education and Care in the Time of COVID-19: Introduction to a Special Issue of Early Childhood Education Journal
}

\author{
Jyotsna Pattnaik ${ }^{1}$ - Mary Renck Jalongo ${ }^{2}$
}

Accepted: 27 May 2021 / Published online: 17 June 2021

(c) The Author(s), under exclusive licence to Springer Nature B.V. 2021

In the spring of 2020, a customer thanked a grocery store employee for continuing to work during the COVID-19 pandemic and subsequent lockdown, and the cashier replied, "Well, somebody has to pay the rent." This single mother went on to say that her greatest worry was bringing the virus home to her children, ages 3 and 7 . It was difficult to help them understand the stay-at-home order and, the night before, her sons had asked when they would be allowed to see their friends and cousins again. The 7-year-old wanted to know about summer-would they go swimming at the community pool? play baseball? visit grandparents? When she said that she did not know, both of her boys started to cry. She had been trying to think of something to brighten their days in quarantine and searched for outdoor play equipment, but it was far too expensive and had to be assembled. Her plan was to purchase a wading pool when it went on sale at the bargain store next door and make a swing out of rope and a discarded car tire to hang from the tree in their yard. That would be something, at least.

8-year-old Ramaya has been eagerly waiting for over a year for her school to reopen. Oldest among the 3 children, she shoulders a big part of the family's responsibilities such as doing house chores, feeding the goats, taking care of her younger siblings, fetching water from a distant well, and gathering fuel. With the intervention of a local non-governmental/nonprofit organization (NGO) last year, Ramaya joined several other children from her village and began attending school. School was a safe place for her that provided some respite from 6 hours of menial work and

Mary Renck Jalongo

mjalongo@comcast.net

Jyotsna Pattnaik

jyotsna.pattnaik@csulb.edu

1 California State University, Long Beach, EED 37, 1250 Bellflower Boulevard, Long Beach, CA 90840, USA

2 Emerita, Indiana University of Pennsylvania, 654 College Lodge Road, Indiana, PA 15701-4015, USA scolding from her mother if Ramaya did not do her chores properly or on time. At school, she imagined herself as the heroine of the stories that her teachers read aloud. Ramaya received recognition for her schoolwork, particularly her drawings and handwriting, and the teacher even gave her some toys to keep. During recess, Ramaya loved to play traditional games from India, such as Phoogadi and Goaph, with her friends. She and her 6-year-old younger brother were provided with breakfast and lunch through the school's free meal program. Now Ramaya is worried that she will not even remember how to read, write, and do mathematics by the time that school reopens. During lockdown, she is not even allowed to play with her friends in the community. Ramaya understands her single mother's stress. With the loss of daily wages, her family of 5 does not have enough to eat. Her mother has a contract to make cardboard boxes and face masks, which will bring in some money. However, Ramaya doubts that it will be enough for her mother to buy a pair of anklets with bells that the 8-year-old wanted to participate in a school dance event. Who knows if or when school will reopen and, even if it does, there may not be enough money for the school to provide anything beyond the absolute basics. Her mother has more important things to worry about than Rayama's dreams of dance. All three of the children missed their free routine immunizations and now their grandmother urgently needs cataract surgery.

These two cases urge us to acknowledge the existence of different childhoods around the world and how the recent health pandemic has affected the human landscape. Not only children's daily lives/basic needs but also their hopes and dreams are shaped by the economic realities of their families, communities, and countries. The experiences of young children in these scenarios also illustrate how the pandemic, with its duration and intensity, has disrupted the lives that children and families lived before the pandemic; furthermore, those adverse influences are multidimensional, with implications for psychological wellbeing, academic achievement, health/nutrition, family financial status, and 
interpersonal relationships. These two dramatically different representations of children's lives remind scholars to consider these realities as a route to raising awareness, discussing challenges, sharing innovations, and instituting changes to government policies. In this special issue of Early Childhood Education Journal, early childhood care and education experts around the world offer authentic, emic perspectives and capture the profound impact of the COVID-19 pandemic on children and families, programs for young children, preservice/inservice teachers, and teacher educators in postsecondary institutions.

The introduction to the Special Issue is organized into three sections. First, we provide a brief review of the literature. Next, we describe the development of the project, commencing with its initial conceptualization and concluding with its publication. Finally, we discuss the significance of the recent global health pandemic and its future implications for the field of early childhood education and care (ECEC).

\section{Brief Review of the Literature}

The world has witnessed various health pandemics prior to COVID-19 outbreak. What distinguishes this pandemic from previous world health crises is its scope, duration, and impact. Since its outbreak, the COVID-19 pandemic has spread to over 200 countries (Jackson et al., 2021) and infected over 153 million people globally with over 3.5 million fatalities. According to UNICEF's (2021) latest estimate, the pandemic has disrupted 1.6 billion children's education worldwide. The data gathered through the Global Education Recovery Tracker shows that, by early March 2021, in-person education was being implemented in just 51 countries. Meanwhile, in more than 90 countries, multiple modalities (e.g., online, hybrid, or complete school closures) were in place (UNICEF, 2021b). Even before the dire situations caused by the pandemic, $43 \%$ of all children under 5 years of age in the world were estimated to be at risk of not achieving their developmental potential (Black et al., 2020). On a global scale, Save the Children (2020) estimates that 9.7 million students-particularly girls living in extreme poverty-will never return to school after the pandemic. Referring to the "inequality catastrophe" resulting from this pandemic, The World Bank (2021) projects that not only girls, but also other vulnerable groups such as children with disabilities, ethnic minorities, refugees, and displaced populations may not resume their education after school reopens. Experts raise the issue of learning loss among children. For example, Jaime Saavedra, World Bank Global Director for Education, estimates that with preschool and school closures, the rate of "learning poverty" (the proportion of 10-year-olds unable to read a short, age-appropriate text) will jump by $10 \%$ within a year into the pandemic
(UNICEF, 2021a). Such learning losses are not unique to countries with widespread poverty, however. Experts in the U.S. and Europe have reported (either through estimation or from their empirical research) that heavy learning losses will affect students well after they return to school (Engzell et al., 2021; Kuhfeld et al., 2021) and that children with the fewest resources prior to the crisis will suffer the most deleterious effects, with $1 \frac{1}{2}$ to $1 / 3$ of them experiencing a "lost year" of school.

A recognition of the individual, daily struggles of families and young children living through the COVID-19 pandemic can be overshadowed by bar graphs and maps that depict the spread of the virus. In the United States, the majority of "essential workers" in various occupations-those who put their lives at risk and continued to work, even during lockdown-are female. The New York Times, for example, reported that women represent 9 out of 10 nurses/nurse assistants and 2/3 of all grocery and fast-food workers (Robertson \& Gebeloff, 2020). Approximately $97 \%$ of early childhood teachers are female, seriously underpaid, and often are without health insurance (U.S. Department of Education, 2016). Many of these individuals were no doubt already struggling financially before COVID hit and it remains to be seen if they will recover from the unanticipated and acute economic impact of the Coronavirus.

Even among middle- and high-income families, quarantines and lockdowns have affected daily life. A Canadian study of 254 families with young children found that over half of them changed their eating habits (e.g., eating more snack foods, spending more time cooking); increased screen time (74\% of mothers, $61 \%$ of fathers and $87 \%$ of children); and decreased physical activity (59\% of mothers, $52 \%$ of fathers and 52\% of children) (Carroll et al., 2020). Parents also reported feeling more stressed about financial instability and the challenge of balancing work demands with childcare and homeschooling (Carroll et al., 2020). Thus, even with many resources and supports in place, the pandemic and responses to it have changed the way that families live. In most cases, those changes were not for the better. A comparative study of seven European countries found that parents reported negative experiences during the pandemic for themselves and their children. Those adverse effects included increased conflict within households, heightened parental alcohol/drug use, dissatisfaction with online education, unsuitability of virtual learning for the youngest children, and inadequate support for homeschooling (Thorell et al., 2021).

In 2020, The International Monetary Fund (2020) predicted a worldwide economic recession to extend beyond 2021. Even if the pandemic could be contained, an estimated additional 42 to 66 million children would be living in extreme poverty (United Nations, 2020). In 2021, economists reported that, although the global economic 
situation recovered somewhat from its 2020 fall, resurgence of the virus in many parts of the world poses a persistent threat to financial stability. The United States Congressional Research Service contends that,

Despite a rebound in some key economic indicators from the depths of the pandemic-related economic recession in early 2020, a growing list of economic indicators makes it clear the COVID-19 pandemic continues to negatively affect global economic growth on a scale not experienced since at least the global financial crisis of 2008-2009, 8.8\% of global working hours were lost in 2020 relative to the fourth quarter of 2019, an amount equivalent to 255 million fulltime jobs (Jackson et al., 2021, p. 2, p. 5).

In March 2021, the International Monetary Fund (2021) projected global growth rate of $6 \%$ in 2021 moderating to a $4.4 \%$ in 2022; however, it also acknowledged high uncertainties surrounding its projection due to a host of factors such as unpredictability of the path of the pandemic, success of vaccination efforts, and the evolution of financial conditions. In an extensive review of the literature, an international group of pediatricians concluded:

Employment may take years to be recuperated in some sectors, and loss of productive assets and business loss may be unrecoverable. The duration of childhood poverty may therefore span all of the early childhood years or beyond. Studies of economic crises as well as birth cohort studies in high as well as low- and middle-income countries demonstrate the potential for life-long negative effects of exposure to poverty early in life, with more severe effects associated with longer exposure to poverty (Yoshikawa et al., 2020).

We produced this Special Issue of Early Childhood Education Journal because the COVID-19 crisis has had profound implications for young children, families, and the entire field of early childhood education and care (ECEC). The youngest children are especially vulnerable to environmental adversity because the years from infancy through age eight represent a critical period when development proceeds rapidly, the structure of the body and the architecture of the mind are being formed, and the foundations are laid for later learning.

There is little question that the Draconian measures instituted worldwide resulted in deeply troubling times, with every type of planning disrupted and important activities put on hold or abandoned. Early childhood programs for children, families, teachers, and teacher educators that have taken years of work to build have ceased to operate. Some surely will not survive. Throughout it all, there is the oppressive weight of worrying and waiting to see what this dreaded virus-and the measures taken to quell it-might do next to threaten the quality of life as we know it.

\section{Development of the Special Issue of Early Childhood Education Journal}

When we first began discussing a Special Issue on the impact of COVID-19 on early childhood in late winter of 2020, we could not predict the havoc that the Coronavirus would wreak on human lives over such an extended period. We turned to the literature published by Springer Nature, the company that sponsors Early Childhood Education Journal. Now the largest publisher of professional materials in the world, they responded nimbly by making all their publications related to the pandemic open access-free of charge and accessible to anyone with an internet connection and reading device. They also put various plans in place to fast-track the peer review process and get current, curated information disseminated to professionals as rapidly as possible. This was accomplished, even though many Springer Nature staff members had to quickly adapt to working from home themselves and strive to keep the publication of journals and books on schedule. As anticipated, in early 2020 there was very little published about the effects of the global pandemic on early childhood education and care-something that underscored the need for high-quality publications on the topic. Yet, casting a wider net to include all the social sciences and using major search engines made it evident that scholars throughout the world from different disciplinary backgrounds were studying the situation, had prior experiences with other pandemics, or were in a geographic region that had a longer history with COVID-19. These perspectives enabled us to envision a plan that we set forth in a Call for Papers. In that document, posted in June of 2020, we noted that:

- The COVID-19 pandemic has resulted in monumental changes to education throughout the world. According to UNESCO (2020), nearly $90 \%$ of the world's student population-over 1.5 billion learners in 165 countrieshave had their learning experiences disrupted by precautions and policies implemented to halt the spread of the disease.

- This global health crisis is the "largest simultaneous shock to all education systems in our lifetimes" (World Bank, 2020).

- Worldwide, the COVID-19 has also pushed the early childhood education system to a verge of collapse and mobilized leading early childhood organizations to advocate for COVID-19 financial packages to protect early education programs (National Association for the Education of Young Children, 2020; Zero to Three, 2020) 
- Children are inherently vulnerable because they depend on adults to have their most basic needs met. When those adults lack the wherewithal to cope with the immediate, urgent, and multiple adaptive demands a pandemic places on families and when support systems do not exist, falter, or cease, it can result in unmitigated disaster for the very young.

- The most affected "are those individuals routinely disadvantaged by the social injustice created by the misdistribution of power, money and resources" (Xafis, 2020, unpaged). Particularly for children who are living in poverty, chronically ill, have disabilities, experience housing and food insecurity, reside in remote areas, are marginalized by mainstream society (e.g., indigenous people and migrant workers), or are suffering from neglect or abuse, problems are exacerbated.

- As concerning as these immediate and observable consequences of COVID-19 for young children are, even less is known about what the long-term effects may be.

- From a scholar's perspective, we are now "participants in the biggest unplanned experiment that education has ever seen in our lifetimes" (Thomas \& Rogers, 2020, unpaged).

When we proposed a special issue of ECEJ focusing on COVID-19, Springer Nature gave their immediate and enthusiastic support to the concept.

Next, we outlined a plan for identifying authors. Through a series of email conversations and examining the Calls for Papers of other editors, we began to formulate a strategy. The first challenge was that the typical way of identifying contributors-by looking at their previous publications on the subject matter-was virtually inaccessible, given the recency of the topic. It was nearly impossible to determine who in our field was engaged already in inquiry related to the pandemic. Furthermore, there was no way to predict which teacher/scholars were sufficiently interested in researching the pandemic phenomenon, becoming well steeped in the international and interdisciplinary literature, and writing about some aspect of the pandemic. Nevertheless, there was a definite need for accurate and up-to-date information about COVID-19 and early childhood education and care.

In the Call for Papers, we emphasized that the focus was on children from infancy up to and including 8 years of age and that the readership of ECEJ consisted primarily of professionals who specialize in the care and education of the very young as well as college/university faculty responsible for teacher preparation, professional development, and graduate study. We explained that we would be receptive to different types of manuscripts: reviews of research that included implications for early childhood practice; original research-quantitative, qualitative, and mixed methods; and manuscripts that offered a critical analysis of existing policies and provided recommendations for the future. Of course, any research had to conform to ethical standards, principles of informed consent, and postsecondary faculty members needed to verify that the research had been approved by their Institutional Review Boards at their college or university. We generated lists of possible topics and then combined/refined them, emphasizing that this was by no means an exhaustive list. We included such topics as history of health pandemics and their consequences for young children, intra/interagency collaborations to support families, impact on teachers and caregivers, supports for student with special needs and other vulnerable populations, administrators' perspectives on the on the impact of COVID-19, effects on professional development, critical analysis of government policies, efforts to maintain professional standards for teacher preparation and practica, and consequences for scholarship in the early childhood field. We emphasized that, given the diverse, international readership of Early Childhood Education Journal and the interdisciplinary implications of a world health crisis, we were particularly eager to see collaborative efforts that looked beyond the local context and involved networking with other early childhood experts, as well as professionals in related fields.

After completing the Call for Papers, we worked closely with the current editor-in-chief of Early Childhood Education Journal, Patricia Crawford, and the staff at Springer Nature to publicize the document through their online presence. We also disseminated the Call for Papers through various listservs of faculty members specializing in early childhood education and care.

The deadlines were extremely tight, but we wanted to get information out to our readers in a timely fashion. At first, the abstracts trickled in slowly, causing us to wonder if the lives of teacher/scholars had been so disrupted or derailed by the pandemic that they had not pursued research on the topic. Given the stringent timeline, we had requested abstracts for the first round of submissions, rather than fully developed manuscripts. As the submission deadline approached, over $100 \mathrm{abstracts}$ were received and reviewed, Of course, even an accepted abstract did not guarantee that the article would be written, much less accepted for publication. In general, we chose those that showed the greatest promise of yielding a publishable article, based on criteria such as: suitability for the readership of ECEJ, academic writing style, level of synthesis in the literature review, and work completed thus far on the study. In the final count, 38 completed manuscripts were submitted to this Special Issue of Early Childhood Education Journal that focused on the effects of COVID19 on Early Childhood Education and Care (ECEC). Each manuscript was evaluated by $2-3$ reviewers and authors were provided with exceptionally detailed feedback to facilitate the revision process. Ultimately, the editor-in-chief accepted the 16 articles featured in this issue of ECEJ. 


\section{Future Implications}

From the time that COVID-19 was first identified to the time of this publication, the burning questions have changed to some extent depending on one's positionality on the world map as well as the extent of the spread of the disease within a country. At first, it was mainly disbelief across the world: "How can this be happening?" Then, as the crisis dragged on, it became "When will it end?" and "Will it ever end?" A handful of nations such as China, South Korea, Singapore, and Australia managed to contain the virus at the beginning phases of the spread; they opened their schools and other institutions and protected their country's educational, health, and economic wellbeing. However, many others-including the United States, Brazil, many European nations, India, and Mexico-were not so fortunate. At the time of this writing, although vaccines are being administered, the rate of distribution differs among nations. The disparity in access to immunization has been glaring. While some wealthy nations could afford to vaccinate more than half of their population, many other nations-particularly those in which poverty is widespread-lag far behind. So, the questions that are raised vary. The global North is raising questions that relate to hopes for speedy recovery and a promising post-COVID-19 society, such as: "Does this mean we will recover as individuals, families, communities, and nations?" "What lasting damage will there be?" and "What plans and preparation should we embark upon that will prove effective?" Meanwhile, people in the global South tend to have questions related to their immediate reality, such as: "Will there be enough vaccine for the entire country and, if so, when?" "How effective is the vaccine that we receive?" "Will my family and I survive if the lockdown continues?" And nearly everyone continues to wonder, "What will the aftermath look like? Could it happen again, with another virus?".

As we write this introduction to the Special Issue, the COVID-19 situation is still fluid. The battle with the virus is continuing in many parts of the world. On April 25, 2021 India reported a single-day total of 350,000 new cases and Brazil's viral-related death count by the end of April 2021 was over 350,000. Uncertainties still surround the educational future of children around the world. Families and ECCE programs are in a constant state of flux. Schools are moving through phases of opening and closing. In many counties where poverty is widespread, a whole year of education was lost for children in low-income communities. Although state and national governments sometimes provided free online materials though television channels, online portals, What's App, and emails, many children could not participate in online learning. Limitations such as their family's lack of technological devices, absence of adequate internet services, or inability to buy more data to send and receive educational materials via their telephones all interfered with online learning. UNICEF's (2021b) estimate is that at least $1 / 3 \mathrm{rd}$ of all school children worldwide have been unable to access remote learning during the pandemic.

Without question, COVID-19 has exacted a heavy toll on human beings not only in terms of mortality rates and longterm health consequences but also in terms of disrupting and destroying social networks. These uncertain times test our collective ability to quickly adapt, cope with multiple personal and professional challenges, and support those most burdened by the shockwaves of COVID-19. Perhaps now, more than ever before, young children and families, teacher candidates, and graduate students are relying on experts in the field of early childhood to support, advocate, and lead. The articles that follow have brought together an international group of teacher/scholar/researcher/authors to examine the implications of a world health pandemic on early childhood education and care. As readers review the table of contents, it is evident that this compilation of scholarly work serves to systematically investigate key aspects of the current pandemic, thereby providing readers with a more nuanced understanding of the consequences of COVID-19 for young children. The perspectives represented in this body of work also underscore how unprepared and underprepared entire nations were to support the care and education of children when confronted by a global health crisis. As contributors to this special issue, all of us lend our voices to global child advocacy efforts and urge national governments to recognize that, if we are to have any hope of recovery, it is essential to make the care and education of young children a top priority. That commitment to young children needs to be as international as the pandemic itself and extend beyond racial, ethnic, cultural, and geographic boundaries. It is then-and only then-that the effort will be equal to the daunting task of rebounding from so much loss and propelling our postpandemic world forward.

\section{References}

Black, M. M., Walker, S. P., Fernald, L. C., Andersen, C. T., DiGirolamo, A. M., Lu, C., McCoy, D. C., Fink, G., Shawar, Y. R., Shiffman, J., Devercelli, A. E., Wodon, Q. T., Vargas-Barón, E., \& Grantham-McGregor, S. (2017). Early childhood development coming of age: Science through the life course. The Lancet, 389, 77-90. https://doi.org/10.1016/S0140-6736(16)31389-7

Carroll, N., Sadowski, A., Laila, A., Hruska, V., Nixon, M., Ma, D. W. L., \& Haines, J. (2020). The impact of COVID-19 on health behavior, stress, financial and food security among middle to high income Canadian families with young children. Nutrients, 12(8), 2352. https://doi.org/10.3390/nu12082352 
Engzell, P., Frey, A., \& Verhagen, M. D. (2021). Learning loss due to school closures during the COVID-19 pandemic. Proceedings of the National Academy of Science, 118(17), e2022376118. https:// doi.org/10.1073/pnas.2022376118

International Monetary Fund. (2020). Projections for global economic recession. www.imf.org/en/News/Articles/2020/03/27/sp032720opening-remarks-at-press-briefing-following-imfc-conference-call

International Monetary Fund. (2021). World economic outlook reports. https://www.imf.org/en/Publications/WEO

Jackson, J. K., Weiss, M. A., Schwarzenberg, A. B., Nelson, R. M., Sutter, K. M., \& Sutherland, M. D. (2021). Global economic effects of COVID-19. Congressional Research Service. https://fas.org/ sgp/crs/row/R46270.pdf

Kuhfeld, M., Soland, J., Tarasawa, B., Johnson, A., Ruzek, E., \& Liu, J. (2020). Projecting the potential impacts of COVID-19 school closures on academic achievement. (Ed WorkingPaper: 20-226). https://doi.org/10.26300/cdrv-yw05

National Association for the Education of Young Children (2020). NAEYC COVID-19 statement. https://www.naeyc.org/resources/ blog/naeyc-covid-19-statement

Robertson, C., \& Gebeloff, R. (2020). How millions of women became the most essential workers in America. The New York Times. https://www.nytimes.com/2020/04/18/us/coronavirus-womenessential-workers.html action $=$ click $\&$ module $=$ Spotlight $\&$ pgtype $=$ Homepage

Save the Children (2020). Almost 10 million children may never return to school following COVID-19 lockdown. https://www.savethechi ldren.org/us/about-us/media-and-news/2020-press-releases/10million-children-may-never-return-toschool-following-coron avirus-lockdown

Thomas, M. S. C., \& Rogers, C. (2020). Education, the science of learning, and the COVID-19 crisis. Prospects, 49, 87-90.

Thorell, L. B., Skoglund, C., de la Peña, A. G., Baeyens, D., Fuermaier, A. B., Groom, M. J., Mammarella, I. C., van der Oord, S., van den Hoofdakker, B. J., Luman, M., \& de Miranda, D. M. (2021). Parental experiences of homeschooling during the COVID-19 pandemic: Differences between seven European countries and between children with and without mental health conditions. European Child and Adolescent Psychiatry. https://doi.org/10. 1007/s00787-020-01706-1

U. S. Department of Education. (2016). Fact sheet: Troubling pay gap for early childhood teachers. https://www.ed.gov/news/press-relea ses/fact-sheet-troubling-pay-gap-early-childhood-teachers

United Nations Educational, Scientific and Cultural Organization (UNESCO). (2020). COVID-19 educational disruption and response. UNESCO. https://en.unesco.org/news/covid-19-educa tional-disruption-and-response
UNICEF Global Educational Recovery Tracker (2021). New global tracker to measure pandemic's impact on education worldwide. https://www.unicef.org/press-releases/new-global-tracker-measu re-pandemics-impact-education-worldwide

United Nations International Children's Emergency Fund (UNICEF). (2021a). How the COVID-19 pandemic has scarred the world's children. https://www.unicef.org/coronavirus/COVID-19-pande mic-scarred-world-children

United Nations International Children's Emergency Fund UNICEF. (2021b). At least one-third COVID-19: At least a third of the world's schoolchildren unable to access remote learning during school closures, new report says. https://www.unicef.org/pressreleases/covid-19-least-third-worlds-schoolchildren-unableaccess-remote-learning-during\#: :text=NEW\%20YORK $\% 2 \mathrm{C} \%$ 2027\%20August $\% 202020, \% 2$ Dto\%2Dschool'\%20plans

United Nations. (2020). Policy brief: The impact of COVID-19 on children. https://unsdg.un.org/resources/policy-brief-impactcovid-19-children

World Bank. (2020). The COVID-19 pandemic: Shocks to education and policy responses. https://www.worldbank.org/en/topic/educa tion/publication/the-covid19-pandemic-shocks-to-education-andpolicy-responses

World Bank. (2021). Urgent, effective action required to quell the impact of COVID-19 on education worldwide. https://www.world bank.org/en/news/immersive-story/2021/01/22/urgent-effectiveaction-required-to-quell-the-impact-of-covid-19-on-educationworldwide

Xafis, V. (2020). 'What is inconvenient for you is life-saving for me': How health inequities are playing out during the COVID-19 pandemic. Asian Bioethics Review, 12, 223-234. https://doi.org/10. 1007/s41649-020-00119-1

Yoshikawa, H., Wuermli, A. J., Britto, P. B., Dreyer, B., Leckman, J. F., Lye, S. J., Ponguta, L. A., Richter, L. M., \& Stein, A. (2020). Effects of the global coronavirus disease-2019 pandemic on early childhood development: Short- and long-term risks and mitigating program and policy actions. The Journal of Pediatrics, 223, 188-193. https://doi.org/10.1016/j.jpeds.2020.05.020

Zero to Three (2020). How COVID-19 is impacting child-care providers. https://www.zerotothree.org/resources/3398-how-covid-19is-impacting-child-care-providers

Publisher's Note Springer Nature remains neutral with regard to jurisdictional claims in published maps and institutional affiliations. 